\title{
The Moderating Effects of Collectivistic Orientation on Psychological Ownership and Constructive Deviant Behavior
}

\author{
Yang Woon Chung (Corresponding author) \\ Dongguk University \\ 30 Pildong-ro 1-gil, Jung-gu, Seoul 100-715, Korea \\ Tel: 82-2-2260-3929Ｅ-mail: jywchung@dongguk.edu \\ Hyoung Koo Moon \\ Korea University Business School \\ 1 Anam Dong, Sungbuk Gu, Seoul 136-701, Korea \\ Tel: 82-2-3290-1934Ｅ-mail: hkmoon@korea.ac.kr
}

Received: June 9, 2011

Accepted: July 20, 2011 Published: December 1, 2011

doi:10.5539/ijbm.v6n12p65

URL: http://dx.doi.org/10.5539/ijbm.v6n12p65

\begin{abstract}
Psychological ownership has been theorized to result in positive organizational consequences because feelings of ownership can increase an individual's sense of responsibility and prioritize organizational interests. Previous studies have found psychological ownership to be significantly related to job satisfaction, organizational commitment, and organizational citizenship behavior; therefore, this study proposes psychological ownership to be significantly related to constructive deviant behavior because it is considered to be functional behavior that is intended to improve the organization's well-being. Furthermore, this study investigates the moderating effects of collectivistic orientation on psychological ownership and constructive deviant behavior. The study sampled 465 Korean employees and has found psychological ownership to be significantly related to innovative constructive deviant behavior and interpersonal constructive deviant behavior. For the moderating effects, collectivistic orientation moderated the relationships between psychological ownership and organizational constructive deviant behavior and interpersonal constructive deviant behavior.
\end{abstract}

Keywords: Psychological ownership, Constructive deviant behavior, Collectivistic orientation

\section{Introduction}

Feelings of ownership have been theorized to increase a sense of responsibility and shared understanding that results in positive attitudinal and behavioral outcomes. Psychological ownership literature has mainly focused on those consequences such as job satisfaction, organizational commitment, and organizational citizenship behavior (e.g., Mayhew, Ashkanasy, Bramble, \& Gardner, 2007; O'Driscoll, Pierce, \& Coghlan, 2006; Van Dyne \& Pierce, 2004; Vandewalle, Van Dyne, \& Kostova, 1995). Recently, Avey, Avolio, Crossley, and Luthans (2009) examined psychological ownership with deviant behavior and have found it to be negatively correlated which further strengthens the positive effects of psychological ownership. And within deviant behavior, researchers have mentioned that there is another side of deviant behavior that is functional and constructive (e.g., Brief, Buttram, \& Dukerich, 2001; Dehler \& Welsh, 1998; Dodge, 1985; Hackman, 1992; Hanke \& Saxberg, 1985). Further, Galperin (2003) and Warren (2003) have conceptualized constructive deviant behavior and have argued that despite being deviant in nature; constructive deviant behavior emphasizes the good intentions and the favorable outcomes that can be beneficial toward the organization and although constructive deviant behavior has been frequently mentioned, there is a lack of empirical research within constructive deviant behavior.

The aim of this study is to first extend the effects of psychological ownership. Given the significant relationship research has found between psychological ownership and organizational citizenship behavior, feelings of ownership should also be positively related with constructive deviant behavior because it is intended to benefit the organization. Second, psychological ownership has yet to be examined with boundary conditions and this study examines how collectivistic orientation will moderate the relationship between psychological ownership and constructive deviant behavior. Today, organizations are frequently implementing work teams to improve 
organizational performance and the nature of work itself has become less individual-oriented and more team-based; therefore, collectivistic orientation can be an important aspect to understand how an employee reacts to organizational work processes that can affect group processes, group effectiveness, and overall organizational performance. In addition, since collectivistic orientation has not received much academic attention (Eby \& Dobbins, 1997) and has been mentioned to affect deviant behavior (Miles, Borman, Spector, \& Fox, 2002), an individual's collectivistic orientation should be conditional as collectivists will focus on the maintaining the organization's equilibrium while individualists will focus more on self-interests and individual achievements.

\section{Theoretical Background}

\subsection{Psychological Ownership}

Pierce, Rubenfeld, and Morgan (1991) explained psychological ownership to be a state of mind that makes an individual feel a specific target object is his or her own (i.e., "It is MINE!"). Psychological ownership is based on an individual's perception about his or her possession and in general, possessions will generate positive feelings about the target object, feel the target of ownership as an extension of the self, and feel a sense of responsibility toward the target object (Van Dyne \& Pierce, 2004). Hence, psychological ownership toward a target object has psychological and emotional consequences. Possession produces a positive and uplifting effect (Formanek, 1991) that make owned objects to be more attractive and favorable (Beggan, 1992), especially when they are compared to un-owned objects (Nuttin, 1987). In context, feelings of ownership are naturally pleasure producing because possession can result from self-enhancing biases, individual effort, controllability, and approval and acceptance from others (Pierce, Kostova, \& Dirks, 2003). They also mentioned that psychological ownership consists of an affective and cognitive state: the affective state being psychological ownership to be pleasure producing while the cognitive state makes an individual perceive feelings of ownership as it reflects his or her awareness, thoughts, and beliefs regarding the target object. Therefore, psychological ownership is rather a complex phenomenon as these two states compose the core aspects of psychological ownership.

As psychological ownership develops, the individual will likely form a close association with the target object just as what we experience with our own possessions such as our homes, automobiles, and space (Dittmar, 1992). Sartre (1969: 591-592) argued that "the totality of my possessions reflects the totality of my being...I am what I have...What is mine is myself." And James (1890: 291-292) commented that "A man's self is the sum total of all that he CAN call his, not only his body and his psychic powers, but...his wife and children,... his land, and yacht and bank account." Therefore, "What is mine becomes (in my feelings) part of ME," explaining that when individuals develop feelings of ownership, they will perceive possessions as a part of their extended self (Belk, 1988; Dittmar, 1992; Furby, 1978).

\subsection{Constructive Deviant Behaviors}

Most research on deviant behavior has focused on the detrimental consequences such as employee theft, personal aggression, and sabotage. However, there is a different facet of deviant behavior that can result in positive and functional consequences. Robinson and Bennett (1995) mentioned that constructive deviant behavior should also be included within workplace deviance as it violates the organization's norms, rules, and policies just like destructive deviant behavior. Recently, several studies have attempted to theoretically develop and conceptualize a typology identifying constructive deviant behavior as a construct (Galperin, 2003; Spreitzer \& Sonenshein, 2004; Warren, 2003). Warren (2003) broadly defined deviant behavior as behaviors that depart from norms and reference groups and argued that destructive deviant behaviors are socially or organizationally harmful while constructive deviant behaviors are socially or organizationally beneficial. Further, she conceptualized an integrative typology by identifying specific forms of constructive deviant behavior such as tempered radicalism, counter-role behavior, whistle-blowing, principled organizational dissent, exercising voice, prosocial behaviors, organizational citizenship behaviors, and functional or creative disobedience.

Galperin and Burke (2006) defined constructive deviant behavior as voluntary behavior that violates significant organizational norms but contributes to the well-being of an organization and/or its members. They argued that constructive deviant behavior is unauthorized but are helpful acts that can facilitate in achieving organizational goals. They categorized constructive deviant behaviors into three distinct dimensions: innovative organizational constructive deviant behavior, challenging organizational constructive deviant behavior, and interpersonal constructive deviant behavior. Innovative organizational constructive deviant behavior refers to behaviors and unconventional ways that help the organization such as implementing innovative ways to perform daily procedures and developing creative solutions to organizational problems. Challenging organizational constructive deviant behavior refers to behaviors that challenge the existing organizational norms and break organizational rules in order to help the organization such as breaking and bending the rules to perform jobs and violating company procedures to solve organizational problems. And interpersonal constructive behavior refers to behaviors such as disobeying the orders given from a supervisor or reporting a wrong doing by coworkers in 
order to bring a positive organizational change.

Similarly, Spreitzer and Sonenshein (2004) defined positive deviant behavior as intentional behaviors that depart from the norms of a referent group in honorable ways. They emphasized that positive deviant behavior must be praiseworthy and must focus on actions that have honorable intentions, irrespective of their outcomes. However, they did not elaborate the specific types of behavior but rather compared it with four other types of behaviors that have overlapping characteristics: whistle-blowing, organizational citizenship behavior, corporate social responsibility, and creativity/innovation. And they concluded that positive deviant behavior is similar to the four behaviors because they all go beyond the lines of organizational norms and are not practiced by the majority; therefore, making them deviant in nature.

\subsection{Collectivistic Orientation}

Hofstede (1980) researched and identified cultural characteristics that differentiate cultural values. Of the five cultural dimensions, collectivism and individualism have been found to show distinct cultural characteristics as Asian cultures were found to be more collectivistic while many western cultures were more individualistic. Research further extended collectivism to the individual level as collectivistic orientation is the degree an individual emphasizes responsibility to groups and organizations and depending on the situation, an individual may either act collectively or individually (Triandis, 1995). Consequently, studies have shown that there are both collectivists and individualists within a society (Morris, Avila, \& Allen, 1993) and Triandis and Suh (2002) argued that around $60 \%$ of individuals in an individualistic culture will be idiocentric while $60 \%$ of individuals in collectivistic culture will be allocentric. Further, Oyserman, Coon, and Kemmelmeier's (2002) meta-analysis found that between-culture differences in collectivism were "neither as large nor as systematic as often perceived."

To elaborate collectivistic orientation at the individual level, collectivists emphasize four key attributes: (1) they define themselves by their membership in various social groups (Markus \& Kitayama, 1991), (2) they tend to subordinate their personal goals to group goals (Yamaguchi, 1994) and sacrifice personal interests for the sake of collective interests when there are in conflict between personal interests and collective interests (Parsons, 1951), (3) their behaviors are more driven by social norms, duties, and obligations (Bontempo \& Rivero, 1992), and (4) they pay more attention to harmonious social relationships within the in-group, sometimes even at the cost of task achievement (Kim, Triandis, Kagitcibasi, Choi, \& Yoon, 1994). In addition, collectivists perceive themselves highly interdependent with the in-group (Triandis, 1993) which makes them engage in more cooperative behaviors toward the group's interest (Hofstede, 1980; Kagitcibasi \& Berry, 1989). Therefore, collectivists prioritize in-group solidarity (Ungston, Steers, \& Park, 1997) and are more concerned with long-term relationships, conformity, security, and tradition (Tiessen, 1997). In contrast, individualists are more concerned with short-term relationships, achievement, self-direction, social power, and stimulation. Individualists are more willing to accept confrontation with the in-group and accept conflict with the out-group and in general, attribute their success to their own individual ability and blame failure to external factors (Tiessen, 1997). Hence, individualists will prioritize personal interests over the importance of the group's interests because they are more likely to look out for themselves and prioritize the accomplishments of their personal goals (Early, 1989; Wagner \& Moch, 1986) and place more value on autonomy, freedom, assertiveness, and a sense of personal uniqueness (Singelis, 1994).

\section{Hypothesis Development}

\subsection{Psychological Ownership and Constructive Deviant Behavior}

Long (1978) argued that employee ownership can produce positive affect because it provides opportunities to exercise organizational influence. The positive moods enhance a target object's value and make an individual to more likely recall more positive information and experiences that can result in prosocial behaviors such as helping other coworkers (Brief \& Motowildo, 1986). In perspective, studies have found employee ownership to be positively related to satisfaction (e.g., Klein, 1987; Long, 1978) and organizational citizenship behavior literature (e.g., Dalal, 2005; LePine, Erez, \& Johnson, 2002) has found job satisfaction to predict citizenship behavior because satisfied individuals reciprocate by promoting the organization through citizenship behaviors. And as psychological ownership has an affective state (Pierce et al., 2003), feelings of ownership should produce positive evaluative judgments that can promote an individual to reciprocate in behaviors that are beneficial toward the organization. Psychological ownership literature has suggested that a number of positive organizational effects can emerge from feelings of ownership and Pierce et al. (1991) argued that psychological ownership should be positively related to constructive organizational behaviors such as organizational citizenship behavior and organizational efficiency and effectiveness. Furthermore, research has mentioned psychological ownership should be related to feelings of responsibility and stewardship and the willingness to take risk and make personal sacrifice (e.g. Dirks, Cummings, \& Pierce, 1996; Pierce, Kostova, \& Dirks, 2001). 
Therefore, previous studies have found psychological ownership to be significantly related to organizational citizenship behavior and extra-role behavior (e.g., Avey et al., 2009; O'Driscoll et al., 2006; Vandewalle et al., 1995; Van Dyne \& Pierce, 2004) and according to Davis, Schoorman, and Donaldson's stewardship theory, stewards act in the best interests of the principals and as "owners," employees will be likely to engage in behaviors that are pro-organizational and collectivistic rather than individualistic and self-serving and seek to attain organizational objectives such as growth and profitability; therefore, making their behaviors to center toward the organization.

Brief and Motowidlo (1986) argued that owners will have prosocial behavioral feelings because they have more intentions to promote the welfare of the individual, group, and/or organization. And since ownership is associated with pride, it should minimize employee shirking and rather increase an individual's motivation to perform at high levels (Bernstein, 1979) because feelings of ownership have been argued to stimulate common interest, psychological partnership, shared responsibility, collective consciousness, and worker commitment and integration (Pierce et al., 1991). In context, studies in personality have found conscientiousness to be significantly related with organizational citizenship behavior (e.g., Borman, Penner, Allen, \& Motowildo, 2001; LePine, et al., 2002) as conscientiousness employees are more dependable and achievement oriented (Mount, Ilies, \& Johnson, 2006) and are more likely to pursue task-related goals at work (Penney, Hunter, \& Perry, 2011). And as organizational citizenship behavior and constructive deviant behavior are both favorable organizational behaviors and are performed for the sake of the organization, we therefore propose the following:

Hypothesis 1: Psychological ownership will be positively related to constructive deviant behavior.

\subsection{Psychological Ownership, Constructive Deviant Behaviors, and Collective Orientation}

The relationship between psychological ownership and constructive deviant behavior will be moderated by an individual's preference on collectivistic orientation. Individuals with strong collectivistic orientation are likely to engage in behaviors that are beneficial to the organization such as organizational citizenship behavior (e.g., Moorman \& Blakely, 1995; Van Dyne, Vandewalle, Kostova, Latham, \& Cummings, 2000) and are less likely to engage in constructive deviant behavior because constructive deviant behavior is not in congruence with organizational policies and norms. Collectivists strongly embrace organizational norms and values and feel that it is their duty and obligation to follow organizational policies and norms. Further, collectivists emphasize harmonious interpersonal relationships within the in-group (Kim et al., 1994) and do not prefer to stand out from their group by competitive acts of achievement (Kitayama, Markus, \& Lieberman, 1995). Therefore, collectivistic orientation will buffer the relationship between psychological ownership and constructive deviant behavior because collectivists are more likely to internalize with the organization's values as their own and therefore be less likely to engage in constructive deviant behavior.

On the contrary, individualists are more likely to engage in behaviors that may benefit themselves due to their motivation to satisfy their own personal self-interests and immediate gratification of needs. Individualists emphasize personal outcomes and value competitiveness, autonomy, and achievement and perceive diversity as bringing unique qualities and multiple perspectives on solving problem (Eisenhardt \& Tabrizi, 1995). Also, individualists are more likely to perceive functional heterogeneity as a positive characteristic that improves group effectiveness (Sosik \& Jung, 2002) and Kim and Markus (1999) suggested that uniqueness can be perceived as a form of deviant behavior while conformity is associated with harmony in a more collectivistic culture; therefore, we propose the following:

Hypothesis 2: Collectivistic orientation will moderate the relationship between psychological ownership and constructive deviant behavior as high collectivistic orientation will weaken the relationship while low collectivistic orientation will strengthen the relationship.

\section{Methodology}

\subsection{Sample}

The study sample was intentionally diversified in order to increase the response variance for deviant behavior. The sample consisted of numerous organizations and varied in organizational characteristics such as industry and size. Out of the 534 respondents, 465 surveys were usable ( 87.08 percent), as cases with missing data on one or more variables were deleted. Of the 465 cases, 62 percent were male and 39 percent female. The mean age was 32.22 years (s.d. 6.51) and the average for organizational tenure was 4.61 years (s.d. 5.12). The majority of the sample had a college degree (60.2 percent) and was within the entry level position (41.1 percent).

\subsection{Measures}

Psychological ownership was measured with Pierce, Van Dyne, and Cummings' (1992) 5-item scale. The items measured how much ownership an individual perceived about his/her organization (e.g., "I sense that this is my company" and "I feel a very high degree of personal ownership for this company"). The Cronbach's coefficient 
alpha was .933 .

Constructive deviant behavior was measured with Galperin's (2002) measure of constructive workplace deviance. The 16-item scale measured the three dimensions of constructive deviant behavior: innovative organizational constructive deviant behavior (e.g., "Developed creative solutions to problems" and "Searched for innovative ways to perform day to day procedures"), challenging organizational constructive deviant behavior (e.g., "Sought to bend or break the rules in order to perform your job" and "Departed from organizational requirements in order to increase the quality of services/products/job"), and interpersonal constructive deviant behavior (e.g., "Did not follow the orders of your supervisor to improve work procedures" and "Reported a wrong-doing to another person in your company to bring about a positive organizational change"). The Cronbach's coefficient alpha were $.818, .919$, and .889 , respectively.

Collectivistic orientation was measured with Jung and Avolio's (1999) typology. The 9-item scale measured an individual's work preference in terms of whether he or she preferred individualistic or collectivistic preferences (e.g., "I can be more productive in a work group when the group decides what I need to do" and "I achieve my best performance by working on group challenges"). The Cronbach's coefficient alpha was .862 .

Age, gender, education, organizational tenure, and position were obtained as demographic variables. In addition, since deviant behavior is vulnerable to social desirability bias, a shortened version of the Crowne-Marlowe's Social Desirability Scale (Reynolds, 1982) was also included. The 13-item scale was factored in as a control variable and the scale measured the desirability effects of certain situations (e.g., "There have been times when I felt like rebelling against people in authority even though I knew they were right" and "There have been times when I was quite jealous of the good fortune of others").

\subsection{Confirmatory Factor Analyses}

Confirmatory factor analyses (CFA) were conducted to examine the discriminant validity of the constructs in our study using AMOS 18.0. We conducted a confirmatory first-order factor analysis to test whether each dimension of constructive deviant behavior has discriminant validity and as shown in Table 1, the results show that the three-factor model had a better fit $\left(\chi^{2}=170.89, \chi^{2} / d f=5.34\right.$, GFI $=.932$, CFI $=.953$, TLI $=.934$, RMSEA $=.097$ ) in comparison to the other models.

\section{Insert Table 1 - here}

\section{Results}

The means, standard deviations, and correlations for the variables used in the study are shown in Table 2.

\section{Insert Table 2 - here}

Hierarchical multiple regression analysis was used to test the hypotheses. For Hypothesis 1 the demographic variables and the social desirability scale were first entered followed by the predictor variable. As shown in Table 3 , psychological ownership was significantly related to innovative constructive deviant behavior $(\beta=.39, \mathrm{p}$ $<.001)$ and interpersonal constructive deviant behavior $(\beta=.13, \mathrm{p}<.01)$ while not significantly related to organizational constructive deviant behavior. Hence, Hypothesis 1 was partially supported.

\section{Insert Table 3 - here}

For Hypothesis 2, we followed the steps recommended by Baron and Kenny (1986) to test for the moderation effects of collectivistic orientation on psychological ownership and constructive deviant behavior. The predictor and moderator variables were both mean-centered before the regression analysis and Table 3 shows that collectivistic orientation significantly moderated the relationships between psychological ownership with organizational constructive deviant behavior $(\beta=-.15, \mathrm{p}<.01)$ and interpersonal constructive deviant behavior $(\beta=-.11, \mathrm{p}<.05)$ but was not significantly related with innovative constructive deviant behavior. We then plotted the moderation graphs by dividing the two groups by one standard deviation. Figure 1 shows that organizational constructive behavior decreased when employees preferred collectivistic while organizational constructive deviant behavior increased when employees were more individualistic. Figure 2 shows that interpersonal constructive deviant behavior increased for both groups but employees who preferred individualistic orientation engaged in interpersonal constructive behavior more frequently compared to collectivistic employees. Therefore, Hypothesis 2 was also partially supported.

\section{Insert Figures $1 \& 2$ - here}

\section{Conclusion}

\subsection{Discussion}

Feelings of ownership increased the likelihood for employees to implement innovative and unconventional work processes and report other employee's wrongdoing in order to improve organizational effectiveness. As expected, 
psychological ownership was significantly related to innovative constructive deviant behaviors because feelings of ownership are likely to make employees work harder, be constructive, and feel more dedicated to their work. And when employees perceive psychological ownership, it can allow them to believe they have certain rights and are entitled to develop and implement innovative and non-compliant work processes. For interpersonal constructive deviant behavior, psychological ownership is likely to increase responsible behavior that will allow employees to feel it is their duty and obligation to report other employees' wrongdoings in order to protect the organization because if they do not, the wrongdoings may detrimentally affect the organization. Hence, the relationship between psychological ownership and innovative constructive deviant behavior and interpersonal constructive deviant behavior is supported by the stewardship theory (Davis, et al. 1997) as employees with feelings of ownership will be more likely to behave as 'stewards' that are more motivated to act in the best interest of the organization.

However, the insignificant relationship between psychological ownership and organizational constructive deviant behavior is quite intriguing because it suggests that employees were ambivalent about organizational constructive deviant behavior. Employees may be at the crossroads due to the fact that in one side, organizational constructive deviant behavior can improve organizational performance but on the contrary, engaging in constructive deviant behavior violates organizational policies and rules that involves personal risk and discomfort from cognitive dissonance In addition, self-identity is an important aspect for psychological ownership as possessions help define themselves and express self-identity to others (Pierce et al., 2003) and according to the social identity theory, individuals will perceive themselves within social groups (Tajfel \& Turner, 1985) and will be more likely to engage in behaviors that are congruent with the norms within their social identities (Ashforth \& Mael, 1989). Therefore, employees who perceive feelings of ownership may not be comfortable in acts that bend and break organizational policies and rules.

For the moderating effects of collectivistic orientation, the study found collectivistic orientation to buffer the relationship between psychological ownership and organizational constructive behavior. As hypothesized, this confirms that collectivistic orientation promotes an employee to prioritize organizational norms and policies while employees with individualistic orientation centered more on their own individual performance and self-interests. For interpersonal constructive deviant behavior, surprisingly, both collectivistic and individualistic employees were likely to engage in interpersonal constructive behavior, although individualistic employees were more frequently reporting their coworkers' wrongdoing in comparison to collectivistic employees. Individualistic employees may perceive that reporting employee wrongdoing can be more advantageous to them as they want to distinguish themselves from deviant employees and they may also have less concern about interpersonal relationships and concentrate on short-term perspectives. In contrast, collectivists may be more likely to feel discomfort and guilt when they report other employee's wrongdoings because by doing so, it will most likely damage interpersonal relationships that can disrupt organizational harmony and equilibrium. Further, since collectivists prefer to maintain organizational membership, collectivists would not want to be labeled as 'whistleblowers' as they are often ostracized and negatively looked upon within the organization. Hence, this finding supports that employees with collectivistic orientation prioritize organizational harmony and can act as an organizational buffer toward deviant behavior while in the contrary, individualistic orientation focuses more on behaviors that can increase an individual's self-achievements and personal interests.

\subsection{Implications}

Empirical studies on psychological ownership have been sparse and this study can initiate further interest as it opens a new avenue of research. By extending the nomological network of psychological, this study is the first to empirically test the relationship between psychological ownership and constructive deviant behavior and the first to include boundary conditions within psychological ownership. Since psychological ownership may still be considered to be in its nascent stages of research development, our study initializes to understand the diverse effects of psychological ownership on different workplace outcomes such as the different forms of constructive deviant behavior.

From a managerial standpoint, psychological ownership appears to be a phenomenon that can increase organizational effectiveness. However, Pierce et al. (2003) have mentioned that psychological ownership can potentially have a dark side and organizations must realize that ownership feelings can permit employees to engage in deviant behavior as our study has found. According to Sykes \& Matza (1957), neutralization tactics affects an individual's perception on deviant behavior. In perspective, psychological ownership may also distort an employee's perceptions about deviant behavior as they may believe as 'owners,' they have certain organizational rights to engage in deviant behavior because 'owners' have organizational privileges. And through these perceptions, employees may prioritize organizational outcomes while overlooking organizational policies and norms because they are engaging in acts that are in the interest of the organization. In addition, psychological ownership can distort an employee's perception on entitlement because 'as owners,' perception on 
entitlement are likely to increase. Previous studies on employee entitlement perceptions have been found to be problematic as entitlement has been found to be significantly related with non-compliant work behaviors such as aggression, conflict with managers, unethical behavior, self-centered behaviors, and poor working conditions (e.g., Bushman \& Baumeister, 1998; Campbell, Bonacci, Shelton, Exline, \& Bushman, 2004; Harvey \& Martinko, 2009; Levine, 2005).

In addition, the actual consequences of constructive deviant behavior must also be considered because constructive deviant behavior may not always result in organizational improvement. Constructive deviant behavior involves behavioral changes that cannot be foreseen which may then increase organizational uncertainty and organizational costs. For example, interpersonal constructive deviant behavior will be likely to decrease employee cooperation and increase interpersonal conflict which can exacerbate organizational effectiveness. Therefore, organizations must realize that feelings of ownership and constructive deviant behavior have to be managed because they can act as a double edged sword.

\subsection{Limitations and Future Research}

There are a few limitations of this study that must be mentioned. First, the study variables were measured using self-reports that were from the same source and social desirability bias can exist as individuals may have favorably responded to psychological ownership and negatively to constructive deviant behavior. However, these can be justified as we conducted a single-common-method factor analysis and included a social desirability bias score into our regression analysis. Further, several researchers have argued that self-reporting for deviant behaviors is more appropriate and reliable because they usually go undetected (Bennett \& Robinson, 2000). Also, several meta-analyses have shown that self-reporting still has a higher validity than other-reporting for deviant behavior (McDaniel \& Jones, 1988; Ones, Viswesvaran, \& Schmidt, 1993) and Berry, Ones, and Sackett's (2007) meta-analysis found that there was not a significant difference between self-reporting and nonself-reporting for deviant behavior. However, future research should attempt to measure constructive deviant behavior using multiple sources such as peers and supervisors as Stewart, Bing, Davison, Woehr, and McIntyre (2009) have suggested for deviant behavior and Podsakoff, MacKenzie, Paine, \& Bachrach (2000) for organizational citizenship behavior. Second, Triandis and Suh (2002) have stated that societies have both idiocentric and allocentric populations despite the society's collectivistic/individualistic preference. However, the majority of our study sample has preferred collectivistic work orientation due to the Korea's cultural characteristic and in order to further validate the moderating effect of collectivistic orientation, a larger sample for individualistic preferences may be necessary to properly capture the effects of individualistic work preferences. Third, constructive deviant behavior may be differently perceived by different organizational members and may not be prevalent for all employees. For instance, supplementary analysis shows when the entry level employees were only considered, psychological ownership was negatively related to organizational constructive deviant behavior $(\beta=-.15, \mathrm{p}>.05)$. In addition, although insignificant, psychological ownership was positively associated with organizational constructive deviant behavior as organizational status increased. Hence, we can generalize that constructive deviant behavior may not be applicable for all employees as opportunities to engage in constructive deviant behavior may differ among employees with different status. Fourth, other control variables may be more relevant and appropriate when investigating constructive deviant behavior. Since constructive deviant behavior can involve substantial personal risk, an individual's characteristics such as ethical orientation, risk-taking propensity, moral judgment, and empathy should also be considered as control variables as studies have found risk taking to affect deviant behavior (Harris \& Ogbonna, 2006) and the frequency in theft to differ in respect to moral development (Greenberg, 2002).

Due to the study results, we suggest a few research directions. First, our findings suggest that psychological ownership may have different effects on constructive deviant behavior. This relationship should be examined by how and why individuals have motives to both cooperate and compete with each other in order to maximize the collective interest as well as to maximize self-interests at the cost of the collective interest (Ferrin, Bligh, \& Kohles, 2007) as the mixed-motive social dilemma has been frequented in the prisoner's dilemma. In perspective, are there underlying factors that can cause these different behaviors? Also, can the strength of ownership feelings allow individuals to behave in differently? Psychological ownership should also be investigated if there is a curvilinear relationship with behavioral outcomes such as deviant behavior.

Second, additional boundary conditions should be investigated such as affective traits, autonomy, and self-regulatory focus as they can further enhance the relationship between psychological ownership and constructive deviant behavior. Spector and Fox (2002) argued how positive affect and negative affect can influence an individual engaging in counterproductive work behavior and organizational citizenship behavior. Avey et al. (2009) argued that there can be promotive and preventive forms of psychological ownership and according to the regulatory focus theory (Higgins, 1997, 1998), the promotion focus is more concerned with pursuing goals, accomplishments, and aspirations that can motivate development and improvement while the 
prevention focus is more concerned with duties and obligations that ensures stability and safety. Therefore, promotive focus can increase the likelihood of individuals to engage in constructive deviant behavior while the preventive focus will decrease the likelihood of constructive deviant behavior. Third, psychological ownership should further be investigated with dysfunctional deviant behavior such as theft, workplace sabotage, and employee shirking. In theory, psychological ownership should be negatively related deviant behavior but due to the study's findings, psychological ownership may have potential to be positively related to certain forms of workplace deviant behavior as 'owners' may feel they are entitled and have the rights to engage in certain deviant behaviors.

In conclusion, this study highlights the effects of psychological ownership on constructive deviant behavior and the moderating effects of collectivistic orientation. As mentioned, organizations must realize that promoting psychological ownership and constructive deviant behavior can have a double standard as feelings of ownership can result in behaviors that may not always be congruent with organizational norms and rules while constructive deviant behavior may have good intentions toward the organization but it involves in employees violating organizational norms and policies.

\section{References}

Ashforth, B.E., \& Mael, F. (1989). Social identity theory and the organization. Academy of Management Review, 14, 20-39. http://dx.doi.org/10.2307/258189

Avey, J.B., Avolio, B.J., Crossley, C.D., \& Luthans, F. (2009). Psychological ownership: Theoretical extensions, measurement and relation to work outcomes. Journal of Organizational Behavior, 30, 173-191. http://dx.doi.org/10.1002/job.583

Baron, R.M., \& Kenny, D.A. (1986). The moderator-mediator distinction in social psychological research: conceptual, strategic, and statistical considerations. Journal of Personality and Social Psychology, 51, 1173-1182. http://dx.doi.org/10.1037//0022-3514.51.6.1173

Beagerhole, E. (1932). Property: A study in social psychology. New York: Macmillan.

Beggan, J.K. (1992). On the social nature of nonsocial perceptions: The mere ownership effect. Journal of Personality and Social Psychology, 62, 229-237. http://dx.doi.org/10.1037//0022-3514.62.2.229

Belk, R.W. (1988). Possessions and the extended self. Journal of Consumer Research, 15, 139-168. http://dx.doi.org/10.1086/209154

Bennett, R.J., \& Robinson, S.L. (2000). Development of a measure of workplace deviance. Journal of Applied Psychology, 85, 349-360. http://dx.doi.org/10.1037//0021-9010.85.3.349

Bernstein, P. (1979). Workplace democratization: Its internal dynamics. New Brunswik, NJ: Transaction Books.

Berry, C.M., Ones, D.S., \& Sackett, P.R. (2007). Interpersonal deviance, organizational deviance, and their common correlates: A review and meta-analysis. Journal of Applied Psychology, 92, 410-424. http://dx.doi.org/10.1037/0021-9010.92.2.410

Bontempo, R., \& Rivero, J.C. (1992). Individualism-collectivism and global variation in decision making: a meta-analysis. Paper presented at the Academy of Management Meeting at Las Vegas.

Borman, W.C., Penner, L.A., Allen, T.D., \& Motowildo, S.J. (2001). Personality predictors of citizenship performance. International Journal of Selection and Assessment, 9, 52-69. http://dx.doi.org/10.1111/1468-2389.00163

Brief, A.P., \& Motowidlo, S.J. (1986). Prosocial organizational behaviors. Academy of Management Review, 11, 710-725. http://dx.doi.org/10.2307/258391

Brief, A.P., Buttram, R.T., \& Dukerich, J.M. (2001). Collective corruption in the corporate world: Toward a process model. In M.E. Turner (Ed.), Groups at work: Theory and Research, Mahwah, NJ: Lawrence Erlbaum Associates.

Bushman, R.F., \& Baumeister, R. (1998). Threatened egotism, narcissism, self-esteem and direct and displaced aggression: Does self-love or self-hate lead to violence? Journal of Personality and Social Psychology, 75, 219-229. http://dx.doi.org/10.1037//0022-3514.75.1.219

Campbell, W.K., Bonacci, A.M., Shelton, J., Exline, J.J., \& Bushman, B.J. (2004). Psychological entitlement: Interpersonal consequences and validation of a self-report measure. Journal of Personality Assessment, 83, 29-45. http://dx.doi.org/10.1207/s15327752jpa8301_04

Dalal, R.S. (2005). A meta-analysis of the relationship between organizational citizenship behavior and counterproductive work behavior. Journal of Applied Psychology, 90, 1241-1255. http://dx.doi.org/10.1037/0021-9010.90.6.1241 
Davis, J.H., Schoorman, F.D., \& Donaldson, L. (1997). Toward a stewardship theory of management. The Academy of Management Review, 22, 20-47. http://dx.doi.org/10.2307/259223

Dehler, G.E., \& Welsh, M.A. (1998). Problematizing deviance in contemporary organizations: A critical perspective. In R.W. Griffin, A O'Leary-Kelly and J.M. Collins (Eds.), Dysfunctional behavior in organizations: Nonviolent behaviors in organizations, 341-269, Stamford, CT: JAI Press.

Dirks, K.T., Cummings, L.L., \& Pierce, J.L. (1996). Psychological ownership in organizations: Conditions under which individuals promote and resist change. In R.W. Woodman \& W.A. Pasmore (Eds.), Research in organizational change and development, 9, 1-23: Greenwich, CT: JAI Press.

Dittmar, H. (1992). The social psychology of material possessions: To have is to be. New York: St. Martin Press.

Dodge, D. (1985). The over-negativized conceptualization of deviance: A problematic exploration. Deviant Behavior, 6, 17-37. http://dx.doi.org/10.1080/01639625.1985.9967657

Earley, P. (1989). Social loafing and collectivism: A comparison of the United States and the People's Republic of China. Academy of Management Journal, 36, 319-348. http://dx.doi.org/10.2307/2393567

Eby, L., \& Dobbins, G. (1997). Collectivistic orientation in teams: An individual and group-level analysis. $\begin{array}{lllll}\text { Journal of } & \text { Organizational } & \text { Behavior, } & 18, & \text { 275-295. }\end{array}$ http://dx.doi.org/10.1002/(SICI)1099-1379(199705)18:3<275::AID-JOB796>3.0.CO;2-C

Eisenhardt, K., \& Tabrizi, B. (1995). Accelerating adaptive processes: Product innovation in the global computer industry. Administrative Science Quarterly, 40, 84-110. http://dx.doi.org/10.2307/2393701

Ferrin, D.L., Bligh, M.C., \& Kohles, J.C. (2007). Can I trust you to trust me?: A theory of trust, monitoring, and cooperation in interpersonal and intergroup relationships. Group \& Organization Management, 32, 465-499. http://dx.doi.org/10.1177/1059601106293960

Formanek, R. (1991). Why they collect: Collectors reveal their motivations. Journal of Social Behavior and Personality, 6, 275-286.

Furby, L. (1978). The socialization of possession and ownership among children in three cultural groups: Israeli kibbutz, Israeli city, and American. In S. Modgil and C. Modgil (Eds.), Piagetian research: Compilation and Commentary (Vol. 8). Windsor, England: National Foundation of Educational Research.

Galperin, B.L. (2002). Determinants of deviance in the workplace: an empirical examination of Canada and Mexico. Unpublished doctoral dissertation. Concordia University, Montreal, Canada.

Galperin, B.L. (2003). Can workplace deviance be constructive? In Sagie, A., Stashevsky, S. and Koslowsky, M. (Eds.) Misbehavior and Dysfunctional Attitudes in Organizations. New York: Palgrave Macmillan, 154-170.

Galperin, B.L., \& Burke, R.J. (2006). Uncovering the relationship between workaholism and workplace destructive and constructive deviance: An exploratory study. International Journal of Human Resource Management, 17, 331-347. http://dx.doi.org/10.1080/09585190500404853

Greenberg, J. (2002). Who stole the money, and when? Individual and situational determinants of employee theft. Organizational Behavior and Human Decision Processes, 89, 985-1003. http://dx.doi.org/10.1016/S0749-5978(02)00039-0

Hackman, J.R. (1992). Group influences on individuals in organizations. In M.D. Dunnette \& L.M. Hough (Eds.), Handbook of Industrial and Organizational Psychology: 199-268. Palo Alto, CA: Consulting Psychologists Press.

Hanke, J.J., \& Saxberg, B.O. (1985). Isolates and deviants in the United States and Japan: Productive nonconformists or costly troublemakers? Comparative Social Research, 8, 219-243.

Harris, L.C., \& Ogbonna, E. (2006). Service sabotage: A study of antecedents and consequences. Journal of the Academy of Marketing Science, 34, 543-558. http://dx.doi.org/10.1177/0092070306287324

Harvey, P., \& Martinko, M.J. (2009). An empirical examination of the role of attributions in psychological entitlement and its outcomes. Journal of Organizational Behavior, 30, 459-476. http://dx.doi.org/10.1002/job.549

Higgins, E. T. (1997). Beyond pleasure and pain. American Psychologist, 52, 1280-1300. http://dx.doi.org/10.1037//0003-066X.52.12.1280

Higgins, E. T. (1998). Promotion and prevention: Regulatory focus as a motivational principle. In M. P. Zanna (Ed.), Advances in experimental social psychology, 30, 1-46. New York: Academic Press.

Hofstede, G. (1980). Cultural consequences. Beverly Hills, CA: Sage.

Isen, A., Shalker, T., Clarke, M., \& Karp, L. (1978). Affect, accessibility of material in memory, and behavior: A 
cognitive loop? Journal of Personality and Social Psychology, 36, 1-12. http://dx.doi.org/10.1037//0022-3514.36.1.1

James, W. (1890). The principles of psychology. New York: Holt.

Jung D.I., \& Avolio, B.J. (1999). Effects of leadership style and follower's cultural orientation on performance in group and individual task conditions. Academy of Management Journal, 42, 208-218. http://dx.doi.org/10.2307/257093

Kagitcibasi, C., \& Berry, J.W. (1989). Cross-cultural psychology: current research and trends. Annual Review of Psychology, 40, 493-531. http://dx.doi.org/10.1146/annurev.psych.40.1.493

Kim, H., \& Markus, H. (1999). Deviance or uniqueness, harmony or conformity? A cultural analysis. Journal of Personality and Social Psychology, 77, 89-100. http://dx.doi.org/10.1037//0022-3514.77.4.785

Kim, U., Triandis, H.C., Kagitcibasi, C., Choi, S.C., \& Yoon, G. (1994). Individualism and collectivism: theory, method, and applications. Sage: Thousand Oaks.

Kitayama, S., Markus, H., \& Lieberman, C. (1995). The collective construction of self-esteem: Implications for culture, self, and emotion. In J. Russell, J. Fernandez-Dols, T. Manstead, \& J. Weelenkamp (Eds.), Everyday conceptions of emotion: An introduction to the psychology, anthropology, and linguistics of emotion (pp. 523-550). Dordrecht, The Netherlands: Kluwer Academic

Klein, K.J. (1987). Employee stock ownership and employee attitudes: A test of three models. Journal of Applied Psychology, 72, 319-332. http://dx.doi.org/10.1037//0021-9010.72.2.319

LePine, J.A., Erez, A., \& Johnson, D.E. (2002). The nature and dimensionality of organizational citizenship behavior: A critical review and meta-analysis. Journal of Applied Psychology, 87, 52-65. http://dx.doi.org/10.1037//0021-9010.87.1.52

Levine, D.P. (2005). The corrupt organization. Human Relations, 58, 723-740. http://dx.doi.org/10.1177/0018726705057160

Long, R.J. (1978). The effects of employee ownership on organizational identification, employee job attitudes, and organizational performance: A tentative framework and empirical findings. Human Relations, 31, 29-48. http://dx.doi.org/10.1177/001872677803100102

Markus, H., \& Kitayama, S. (1991). Culture and the self: implications for cognition, emotion, and motivation. Psychological Review, 98, 224-253. http://dx.doi.org/10.1037//0033-295X.98.2.224

Mayhew, M.G., Ashkanasy, N.M., Bramble, T., \& Gardner, J. (2007). A study of the antecedent and consequences of psychological ownership in organizational settings. The Journal of Social Psychology, 147, 477-500. http://dx.doi.org/10.3200/SOCP.147.5.477-500

McDaniel, M.A., \& Jones, J.W. (1988). Predicting employee theft: A quantitative review of the validity of a standardized measure of dishonesty. Journal of Business and Psychology, 2, 327-345.

Miles, D.E., Borman, W.E., Spector, P., \& Fox, S. (2002). Building an integrative model of extra role work behaviors: A comparison of counterproductive work behavior with organizational citizenship behavior. International Journal of Selection and Assessment, 10, 51-57. http://dx.doi.org/10.1111/1468-2389.00193

Moorman, R.H., \& Blakely, G.L. (1995). Individualism-collectivism as an individual difference predictor of organizational citizenship behavior. Journal of Organizational Behavior, 16, 127-142. http://dx.doi.org/10.1002/job.4030160204

Morris, M.H., Avila, R.A., \& Allen, J. (1993). Individualism and the modern corporation: Implications for innovation and entrepreneurship. Journal of Management, 19, 595-612. http://dx.doi.org/10.1016/0149-2063(93)90006-9

Mount, M., Ilies, R., \& Johnson, E. (2006). Relationship of personality traits and counterproductive work behaviors: The mediating effects of job satisfaction. Personnel Psychology, 59, 591-622. http://dx.doi.org/10.1111/j.1744-6570.2006.00048.x

Nuttin, J.M., Jr. (1987). Affective consequences of mere ownership: The name letter effect in twelve European languages. European Journal of Social Psychology, 17, 229-237.http://dx.doi.org/10.1002/ejsp.2420170402

O'Driscoll, M.P., Pierce, J.L., \& Coghlan, A. (2006). The psychology of ownership: Work environment structure, organizational commitment, and citizenship behaviors. Group and Organization Management, 31, 388-416. http://dx.doi.org/10.1177/1059601104273066

Ones, D.S., Viswesvaran, C., \& Schmidt, F. (1993). Comprehensive meta-analysis of integrity test validities: Findings and implications for personnel selection and theories of job performance. Journal of Applied 
Psychology, 78, 679-703. http://dx.doi.org/10.1037//0021-9010.78.4.679

Oyserman, D., Coon, H.M., \& Kemmelmeier, M. (2002). Rethinking individualism and collectivism: Evaluation of theoretical assumptions and meta-analyses. Psychological Bulletin, 128, 3-72. http://dx.doi.org/10.1037//0033-2909.128.1.3

Parsons, T. (1951). The Social System. Toronto: Ontario: Collier-Macmillan, Canada.

Penney, L.M., Hunter, E.M., \& Perry, S.J. (2011). Personality and counterproductive work behavior: Using conservation of resources theory to narrow the profile of deviant employees. Journal of Occupational and Organizational Psychology, 84, 58-77. http://dx.doi.org/10.1111/j.2044-8325.2010.02007.x

Pierce, J.L., Kostova, T., \& Dirks, K.T. (2001). Towards a theory of psychological ownership in organizations. Academy of Management Review, 26, 298-310. http://dx.doi.org/10.2307/259124

Pierce, J.L., Kostova, T., \& Dirks, K.T. (2003). The state of psychological ownership: Integrating and extending a century of research. Review of General Psychology, 7, 84-107. http://dx.doi.org/10.1037//1089-2680.7.1.84

Pierce, J.L., Rubenfeld, S.A., \& Morgan, S. (1991). Employee ownership: A conceptual model of process and effects. Academy of Management Review, 16, 121-144. http://dx.doi.org/10.2307/258609

Pierce, J.L., Van Dyne, L., \& Cummings, L.L. (1992). Psychological ownership: A construct validation study. In M. Schnake (Ed.) Proceedings of the Southern Management Association. Valdosta, GA: Valdosta State University.

Podsakoff, P.M., MacKenzie, S.B., Paine, J.B., \& Bachrach, D.G. (2000). Organizational citizenship behaviors: A critical review of the theoretical and empirical literature and suggestions for future research. Journal of Management, 26, 513-563. http://dx.doi.org/10.1016/S0149-2063(00)00047-7

Reynolds, W.M. (1982). Development of reliable and valid short forms of the Marlowe-Crowne social $\begin{array}{lllll}\text { desirability scale. Journal of Clinical Psychology, } & 38, & 119-125 .\end{array}$ http://dx.doi.org/10.1002/1097-4679(198201)38:1<119::AID-JCLP2270380118>3.0.CO;2-I

Robinson, S.L., \& Bennett, R.J. (1995). A typology of deviant workplace behaviors: A multidimensional scaling study. Academy of Management Journal, 38, 555-572. http://dx.doi.org/10.2307/256693

Sartre, J.P. (1969). Being and nothingness: A phenomenological essay on ontology. New York: Philosophical Library.

Singelis, T.M. (1994). The measurement of independent and interdependent self-construals. Personality and Social Psychology Bulletin, 20, 580-591. http://dx.doi.org/10.1177/0146167294205014

Smith, C.A., Organ, D.W., \& Near, J.P. (1983). Organizational citizenship behavior: Its nature and antecedents. Journal of Applied Psychology, 68, 653-663. http://dx.doi.org/10.1037//0021-9010.68.4.653

Sosik, J.J., and Jung, D.I. (2002). Work-group characteristics and performance in collectivistic and individualistic cultures. Journal of Social Psychology, 142, 5-23. http://dx.doi.org/10.1080/00224540209603881

Spector, P.E., \& Fox, S. (2002). An emotion-centered model of voluntary work behavior: Some parallels between counterproductive work behavior and organizational citizenship behavior. Human Resource Management Review, 12, 269-292. http://dx.doi.org/10.1016/S1053-4822(02)00049-9

Spreitzer, G.M., \& Sonenshein, S. (2004). Toward the construct definition of positive deviance. American Behavioral Scientist, 47, 828-847. http://dx.doi.org/10.1177/0002764203260212

Stewart, S.M., Bing, M.N., Davison, H.K., Woehr, D.J., \& McIntyre, M.D. (2009). In the eye of the beholder: A non-self-report measure of workplace deviance. Journal of Applied Psychology, 94, 207-215. http://dx.doi.org/10.1037/a0012605

Sykes, G.M., \& Matza, D. (1957). Techniques of neutralization: A theory of delinquency. American Sociological Review, 22, 664-670. http://dx.doi.org/10.2307/2089195

Tajfel, H., \& Turner, J.C. (1985). The social identity theory of intergroup behavior. In S. Worchel \& W.G. Austin (Eds.), Psychology of intergroup relations, 2, 7-24. Chicago: Nelson-Hall.

Tiessen, J.H. (1997). Individualism, collectivism, and entrepreneurship: A framework for international comparative research. Journal of Business Venturing, 12, 367-384. http://dx.doi.org/10.1016/S0883-9026(97)81199-8

Triandis, H.C. (1993) Collectivism and individualism as cultural syndromes. Cross-Cultural Research, 27, 155-180. http://dx.doi.org/10.1177/106939719302700301

Triandis, H.C. (1995). Individualism and collectivism. Boulder, CO: Westview Press. 
Triandis, H.C., \& Suh E.M. (2002). Cultural influences on personality. Annual Review of Psychology, 53, 133-160.

Ungston, G.R., Steers, R.M., \& Park, S. (1997). Korean enterprise: The quest for globalization. Boston: Harvard Business School Press.

Van Dyne, L., \& Pierce, J.L. (2004). Psychological ownership and feelings of possession: Three field studies predicting employee attitudes and organizational citizenship behavior. Journal of Organizational Behavior, 25, 439-459. http://dx.doi.org/10.1002/job.249

Van Dyne, L., Vandewalle, D., Kostova, T., Latham, M.E., \& Cummings, L.L. (2000). Collectivism, propensity to trust and self-esteem as predictors of organizational citizenship in a non-work setting. Journal of Organizational Behavior, $3-23$. http://dx.doi.org/10.1002/(SICI)1099-1379(200002)21:1<3::AID-JOB47>3.0.CO;2-6

Vandewalle, D., Van Dyne, L., \& Kostova, T. (1995). Psychological ownership: An empirical examination of its $\begin{array}{lllll}\text { consequences. Group and } & \text { Trganization }\end{array}$ http://dx.doi.org/10.1177/1059601195202008

Wagner, J., \& Moch, M.K. (1986). Individualism-collectivism: Concept and measure. Group and Organization Studies, 11, 280-304. http://dx.doi.org/10.1177/105960118601100309

Warren, D. (2003). Constructive and destructive deviance in organization. Academy of Management Review, 28, 622-632.http://dx.doi.org/10.2307/30040751

Wilpert, B. (1991). Property, ownership, and participation: On the growing contradictions between legal and psychological concepts. In R. Russell and V. Russell (Eds.), International handbook of participation in organizations: For the study of organizational democracy, co-operation, and self-management (Vol. 2, pp.149-164). New York: Oxford University Press.

Yamaguchi, S. (1994). Collectivism among the Japanese: A perspective from the self. In U. Kim, H.C. Triandis, C. Kagitcibasi, S.C. Choi, \& G. Yoon. (Eds.), Individualism and Collectivism: Theory, method, and applications (pp. 175-188). London: Sage.

Table 1. Results of Confirmatory Factor Analyses

\begin{tabular}{|c|c|c|c|c|c|c|}
\hline Models & $\chi^{2}(d f)$ & $\chi^{2} / d f$ & GFI & CFI & TLI & RMSEA \\
\hline 1. 1-Factor model & $1083.72(35)$ & 30.96 & .704 & .644 & .542 & .254 \\
\hline 2. 2-Factor model ${ }^{\mathrm{a}}$ & $693.76(34)$ & 20.40 & .771 & .776 & .704 & .204 \\
\hline 3. 2-Factor model ${ }^{\mathrm{b}}$ & $701.20(34)$ & 20.62 & .769 & .773 & .700 & .206 \\
\hline 4. 2-Factor model $\mathrm{l}^{\mathrm{c}}$ & $574.15(34)$ & 16.89 & .834 & .817 & .757 & .185 \\
\hline 5.3-Factor model & $170.89(32)$ & 5.34 & .932 & .953 & .934 & .097 \\
\hline
\end{tabular}

a: Innovative constructive deviant behavior \& Organizational constructive deviant behavior, interpersonal constructive deviant behavior

b: Innovative constructive deviant behavior \& Interpersonal constructive deviant behavior, Organizational constructive deviant behavior

c: Organizational constructive deviant behavior \& Interpersonal constructive deviant behavior, Innovative constructive deviant behavior

Table 2. Correlations and Descriptive Statistics

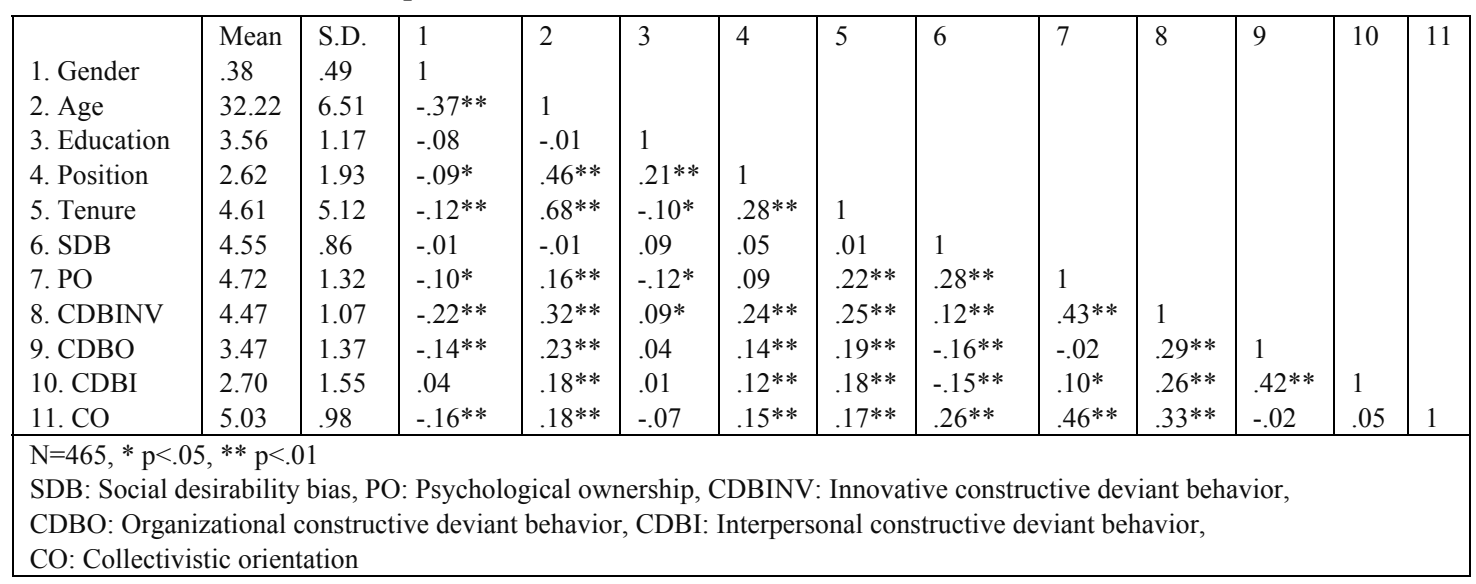


Table 3. Hierarchical Regression Analysis

\begin{tabular}{|c|c|c|c|c|c|c|c|c|c|c|c|c|}
\hline & \multicolumn{4}{|c|}{$\begin{array}{c}\text { Innovative Constructive } \\
\text { Deviant Behavior }\end{array}$} & \multicolumn{4}{|c|}{$\begin{array}{c}\text { Organizational Constructive } \\
\text { Deviant Behavior }\end{array}$} & \multicolumn{4}{|c|}{$\begin{array}{l}\text { Interpersonal Constructive } \\
\text { Deviant Behavior }\end{array}$} \\
\hline & Step 1 & Step 2 & Step 3 & Step 4 & Step 1 & Step 2 & Step 3 & Step 4 & Step 1 & Step 2 & Step 3 & Step 4 \\
\hline Gender & $-.13 * *$ & $-.10^{*}$ & -.08 & -.09 & -.08 & -.08 & -.08 & -.09 & $.11 *$ & $.12 *$ & $.13 *$ & $.12 *$ \\
\hline Age & $.15^{*}$ & $.16^{*}$ & $.16^{*}$ & $.16^{* *}$ & .10 & .10 & .10 & .10 & .14 & $.14^{*}$ & $.14^{*}$ & $.14^{*}$ \\
\hline Education & .06 & $.11 * *$ & $.12 * *$ & $.12 * *$ & .05 & .04 & .04 & .05 & .03 & .05 & .05 & .06 \\
\hline Tenure & .10 & .02 & .02 & .02 & .10 & .10 & .10 & .11 & .10 & .07 & .07 & .08 \\
\hline Position & $.12 *$ & $.10^{*}$ & .09 & .09 & .06 & .06 & .06 & .07 & .04 & .04 & .03 & .04 \\
\hline SDB & $.11 *$ & .00 & -.02 & -.02 & $-.17 * * *$ & $-.16^{* *}$ & $.15^{* *}$ & $-.15 * *$ & $-.15 * *$ & $-.19 * * *$ & $-.20 * * *$ & $-.19 * * *$ \\
\hline PO & & $.39 * * *$ & $.34 * * *$ & $.34 * * *$ & & -.02 & -.01 & .00 & & $.13^{* *}$ & $.12 *$ & $.13^{*}$ \\
\hline $\mathrm{CO}$ & & & $.13 * *$ & $.13^{* *}$ & & & -.03 & -.05 & & & .03 & .01 \\
\hline $\mathrm{POxCO}$ & & & & -.03 & & & & $-.15 * *$ & & & & $-.11 *$ \\
\hline$\Delta \mathrm{R}^{2}$ & .15 & .13 & .01 & .00 & .09 & .00 & .00 & .02 & .08 & .02 & .00 & .01 \\
\hline $\mathrm{R}^{2}$ & .15 & .28 & .29 & .29 & .09 & .09 & .09 & .11 & .08 & .10 & .10 & .11 \\
\hline $\mathrm{F}$ & $13.13 * * *$ & $25.04 * * *$ & $23.21 * * *$ & $20.65 * * *$ & $7.38 * * *$ & $6.33^{* * *}$ & $5.59 * * *$ & $6.39 * * *$ & $6.31^{* * *}$ & $6.58 * * *$ & $5.79^{* * *}$ & $5.88 * * *$ \\
\hline
\end{tabular}

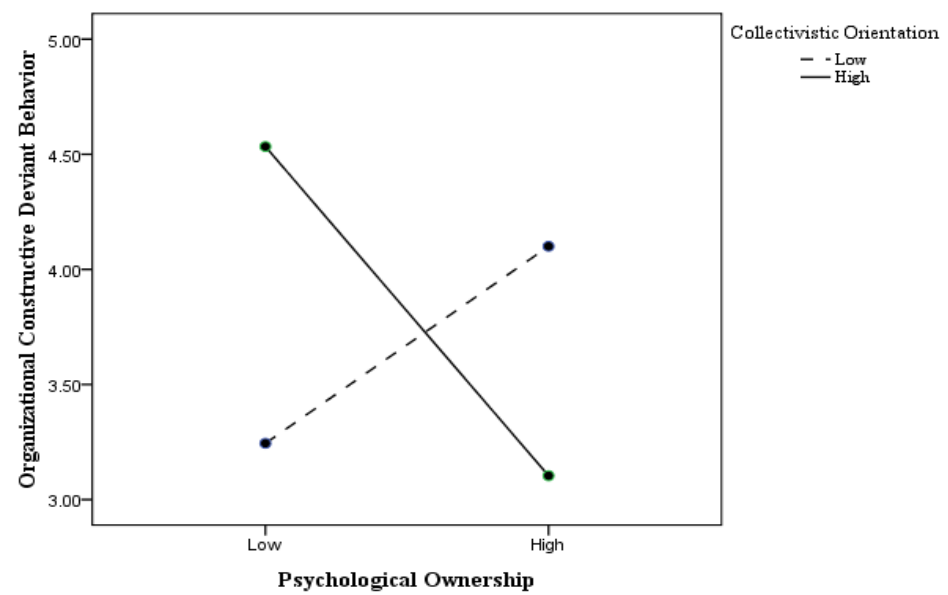

Figure 1. Collectivistic Orientation as a Moderator of the Relationship between Psychological Ownership and Organizational Constructive Deviant Behavior

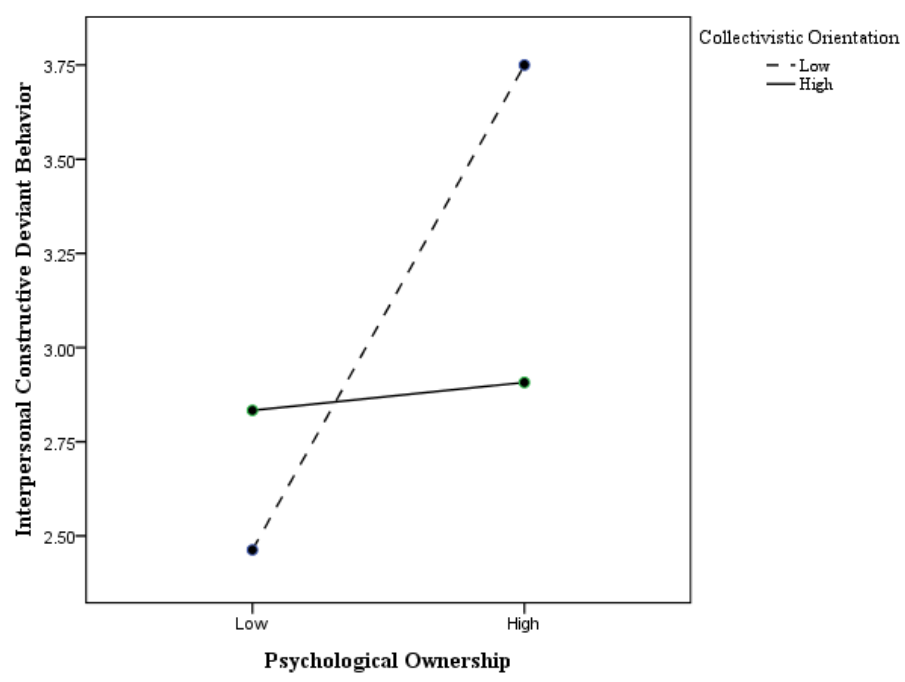

Figure 2. Collectivistic Orientation as a Moderator of the Relationship between Psychological Ownership and Interpersonal Constructive Deviant Behavior 